\title{
Improving forecasts of arctic-alpine refugia persistence with
} landscape-scale variables

\section{Niskanen, Annina K. J.}

2017-02

Niskanen , A K J , Heikkinen , R K, Mod, H K, Väre , H \& Luoto , M 2017 , ' Improving forecasts of arctic-alpine refugia persistence with landscape-scale variables ', Geografiska Annaler. Series A. Physical Geography , vol. 99 , no. 1 , pp. 2-14 . https://doi.org/10.1080/04353676.2016.1256746

http://hdl.handle.net/10138/307291

https://doi.org/10.1080/04353676.2016.1256746

unspecified

acceptedVersion

Downloaded from Helda, University of Helsinki institutional repository.

This is an electronic reprint of the original article.

This reprint may differ from the original in pagination and typographic detail.

Please cite the original version. 
1 Improving forecasts of arctic-alpine refugia persistence with landscape-scale variables

2

\author{
Annina K.J. Niskanen ${ }^{1}$, Risto K. Heikkinen ${ }^{2}$, Heidi K. Mod ${ }^{1}$, Miska Luoto ${ }^{1}$ \\ ${ }^{1}$ Department of Geosciences and Geography, P.O. Box 64 (Gustaf Hällströmin katu 2a), FI-00014 University of Helsinki, \\ Finland; ${ }^{2}$ Finnish Environment Institute, Natural Environment Centre, P.O. Box 140, FI-00251, Helsinki, Finland
}

Niskanen A.K.J., Heikkinen R.K., Mod H.K. and Luoto M., 20xx.. Improving forecasts of arctic-alpine refugia persistence with landscape-scale variables. Geografiska Annaler, Series A: Physical Geography.

\begin{abstract}
Refugia, sites preserving conditions reminiscent of suitable climates, are projected to be crucial for species in a changing climate, particularly at high latitudes. However, the knowledge of current locations of high-latitude refugia and particularly their ability to retain suitable conditions under future climatic changes is limited. Occurrences of refugia have previously been mainly assessed and modelled based solely on climatic features, with insufficient attention being paid to potentially important landscape-scale factors. Here, climate-only models and 'full' models incorporating topo-edaphic landscape-scale variables (radiation, soil moisture and calcareousness) were developed and compared for 111 arcticalpine plant species in Northern Fennoscandia. This was done for both current and future climates to determine cells with resilient climatic suitability harbouring refugia. Our results show that topographic and edaphic landscape-scale predictors both significantly improve models of arctic-alpine species distributions and alter projections of refugia occurrence. Predictions of species-climate models ignore landscape-scale ecological processes and may thus provide inaccurate estimates of extinction risk and forecasts of refugia where species can persist under a changing climate.
\end{abstract}

Keywords: climate change; refugia; landscape-scale factor

\title{
Introduction
}

Previous research has shown the importance of refugia for species survival during past environmental changes (Taberlet, 1998; Birks \& Willis, 2008; Svenning et al., 2008). Refugia are sites that provide environmental conditions deviant from the regional average, thereby supporting species persistence in a changing climate (Médail \& Diadema, 2009; Keppel $e t$ al., 2012). Due to the rate and magnitude of global change, refugia are also likely to be among the major mechanisms assisting species persistence in the future (Reside et al., 2013) and should thus be acknowledged in climate change -based conservation planning. A challenge still remains in the credible identification of present-day refugia across landscapes, and particularly in assessing their capability to retain suitable conditions under future climatic changes. Spatial 
information regarding future refugia is particularly important at high latitudes, as they are among the most susceptible environments to a changing climate (Root et al., 2003; Ashcroft, 2010). However, little is known about which highlatitude landscapes and species are most vulnerable to projected future climatic trends. This knowledge gap calls for increased attention on robust forecasts of how the suitable areas for the species might change, which environmental factors are most critical for developing the most reliable models of this change, and how well potential future refugia are discernible from a given landscape.

Species distribution models (SDMs) are a commonly used tool to forecast the spatial changes in realized or potential species distributions (Guisan \& Thuiller, 2005; Araújo \& Peterson, 2012). SDMs have also been shown to complement and be spatially correlated with traditionally used phylogeographic estimates of past refugia distribution while providing less subjective and spatially more explicit predictions (Waltari et al., 2007). However, it is increasingly recognized that SDMs often require both climatic variables and non-climatic variables describing landscape-scale or local environmental conditions to maximize predictive ability (Franklin, 1995; Austin \& Van Niel, 2011a; Beauregard \& de Blois, 2014). Such integrative modelling studies have not, however, been carried out for arctic-alpine species or their refugia in high-latitude regions. This is a shortcoming as the inclusion of landscape-scale factors into SDMs developed for high-latitude refugia may be of particular significance and help identify locations able to preserve environmental conditions reminiscent of the current climate within the surrounding changing matrix, thus leading to more robust predictions of future refugia (Austin \& Van Niel, 2011a; Hodd et al., 2014).

A frequently applied paradigm in the study of global change impacts on biota involves models of the distributional changes of species - or the areas environmentally suitable for them - as spatially explicit functions of projected change (Guisan \& Thuiller, 2005; Botkin et al., 2007). Similarly, previous studies using spatial models of predicted species distributions have mainly approached refugia from the viewpoint of a single species (Hugall et al., 2002; Austin \& Van Niel, 2011a), past distributions (Fløjgaard et al., 2009) or coarser spatial scales (Hodd et al., 2014). Here, we investigate whether the addition of landscape-scale variables to climate-only SDMs (1) leads to different interpretations of how projected changes in climate may affect the distributions of 111 arctic-alpine plant species, and (2) modifies predictions of in situ refugia for these species in N-Fennoscandia. We base these analyses on high-quality species and environmental data, and predict species distributions under contemporary climate as well as two projected future climates i.e. Representative Concentration Pathway (RCP) scenarios: the moderate RCP 4.5 (Smith \& Wigley, 2006; Clarke et al., 2007; Wise et al., 2009) and extreme RCP 8.5 scenarios (Riahi et al., 2007). 


\section{Materials and methods}

Study area

Located in Northern Fennoscandia between $67^{\circ} \mathrm{N}$ and $70^{\circ} \mathrm{N}$, the sub-arctic climate of our study region is driven by its position at the edge of the Eurasian continent, the Polar Front, the warm North Atlantic current, and proximity to the Scandes Mountains (Fig. 1) (Tikkanen, 2005; Aalto et al., 2014b). The area is characterized by varying climatic, topographic and geologic gradients (Oksanen \& Virtanen, 1995). Average July temperatures range from $6.1{ }^{\circ} \mathrm{C}$ to $15.2^{\circ} \mathrm{C}$ and mean annual precipitation from $449 \mathrm{~mm}$ to $600 \mathrm{~mm}$ (1981 - 2010 means) (Pirinen et al., 2012). Elevation ranges from 72 to 1365 m.a.s.l. The vegetation gradient varies from spruce (Picea abies) and Scots pine (Pinus sylvestris) forests in the south to mountain birch (Betula pubescens subsp. czerepanovii) in the north, with shrub-dominated tundra-like vegetation above the tree-line (Sormunen et al., 2011).

Preliminary data analysis indicated that parts of our study area are predicted to have a future climate with no current equivalent within the study region. To reduce errors from predicting species responses to climatic conditions without current equivalents, and as arctic-alpine species are generally expected to move northwards as the climate warms, we used data from the whole area for training the models, but excluded the non-analogue southern- and easternmost regions of our study area from model projections (dashed line in Fig. 1) (Sætersdal et al., 1998; Heikkinen et al., 2006).

\section{Species data}

Species occurrence data for $13411 \mathrm{~km}^{2}$ cells were collected by botanists and volunteers, and refined using scientific literature and herbaria. The sampling cells cover all important vegetation zones and ecosystems present in the study area, ranging from taiga to treeless tundra (Kurtto \& Lampinen, 1999). Only arctic-alpine species (defined according to biogeographic distribution by professional botanists; see le Roux et al. (2012)) with an occurrence in a minimum of eight cells within our study area were included in the subsequent analysis $(n=111)$.

\section{Selection of predictors}

We used an extensive grid of environmental data matching the resolution of the species data $\left(1 \mathrm{~km}^{2}\right)$ to investigate key refugia predictors. We chose to demonstrate our methodology using a set of climate and landscape-scale terrain and geological variables (Table 1) known to be important for plant species (Skov \& Svenning, 2004; Austin \& Van Niel, 2011a; Dobrowski, 2011; Scherrer \& Körner, 2011). The chosen direct and resource variable predictors (Austin \& Smith, 1990) represent growing conditions, surface temperature, light, moisture and soil conditions considered critical for highlatitude vegetation. 
The climate data, comprising of observations from 61 stations in Northern Fennoscandia, were acquired from the national observation networks of Finland (Finnish Meteorological Institute), Sweden (Swedish Meteorological and Hydrological Institute) and Norway (Norwegian Meteorological Institute), and modelled to a $1 \mathrm{~km}^{2}$ resolution grid (see Aalto et al., 2014). Three climatic predictors with a temporal coverage of 1981-2010 were initially included in the analyses: growing degree days (GDD3; annual accumulated daily temperature sum above $3^{\circ} \mathrm{C}$, i.e. growing conditions), temperature of the coldest quarter (TCQ; overwintering conditions) and water balance (WAB; moisture conditions). However, due to ecologically erroneous projections resulting from the counter effects of different climatic variables caused by variable multicollinearity, (namely strong correlations of GDD3 with TCQ and WAB [Spearman's rank correlation coefficients, $\mathrm{rs}=-0.88$ and $\mathrm{rs}=-0.87$, respectively]), only GDD3, which correlates the most with arctic-alpine species diversity in the study area $(\mathrm{rs}=-0.75)$, was ultimately included in the final models.

Landscape features exert a strong influence through numerous geomorphological, hydrological, geological and biological processes (Moore et al., 1991), thus controlling the growing conditions experienced by plants (Guisan et al., 1998; Ackerly et al., 2010; Scherrer \& Körner, 2011). Here, three topo-edaphic landscape-scale predictors were used: (1) incoming potential solar radiation representing surface temperature conditions (McCune \& Keon, 2002); (2) digital elevation model-derived topographic wetness index (TWI) representing the availability of soil moisture from upslope areas (Beven \& Kirkby, 1979); and (3) calcareousness representing the proportion of calcareous, nutrient-rich bedrock in a given $1 \mathrm{~km}^{2}$ grid cell (Dubuis et al., 2013). In contrast to GDD3, the relative effects of radiation, fluvial processes (e.g. TWI) and soil properties (e.g. calcareousness) should remain more constant in the future (Reside et al., 2013). Radiation and TWI were based on an Aster -derived digital elevation model (NASA Land Processes Distributed Active Archive Center (2013); spatial resolution $30 \mathrm{~m}^{2}$ ). Radiation was calculated using the ArcView 3.2 Solar analyst extension which uses digital elevation models to generate radiation data by accounting for latitude, elevation, slope angle, slope aspect, shadows cast by surrounding topography, daily and seasonal shifts in solar angle, and atmospheric attenuation (Fu \& Rich, 1999). Due to the landscape scale of this study, only one latitude value (here, $69^{\circ}$ ) for the whole digital elevation model was used. TWI, the most often used surrogate for soil moisture, was calculated using a Python script written by Prasad Pathak that accounts for slope and local upslope contributing area (Beven \& Kirkby, 1979; Esri, 2013). Calcareousness was reclassified from a digital database (Geological Survey of Finland 2010; spatial resolution 20 $\mathrm{m}^{2}$ ). The landscape predictors were resampled by spatial averaging to a $1 \mathrm{~km}^{2}$ resolution to match the species and climate data. 
115 Forecasts for the locations of refugia may vary between climate scenarios, thus making it imperative to consider

116 predictions based on multiple scenarios (Reside et al., 2013). Four sets of scenarios containing different emission, concentration and land-use trajectories, have been developed (Van Vuuren et al., 2011). These scenario sets are referred to as Representative Concentration Pathways (RCPs) and they correspond to different greenhouse gas (GHG) concentration trajectories (Moss et al., 2010). Here we explore the implications of two possible future pathways, RCP 4.5 and RCP 8.5 (where the number refers to radiative forcing in watts $/ \mathrm{m}^{2}$ by the year 2100 ). RCP 4.5 is an intermediate mitigation scenario where GHG emissions are stabilized at low to medium levels (Van Vuuren et al., 2011). RCP 8.5, the unabated 'business-as-usual' scenario, represents the highest GHG emission profile (Riahi et al., 2011; Van Vuuren et al., 2011).

\section{Statistical analyses}

Observed species distributions were related to the set of predictors using five statistical modelling techniques. These included two regression methods: generalized linear modeling (GLM) (McCullagh \& Nelder, 1989) and generalized additive modeling (GAM) (Hastie \& Tibshirani, 1990) and three machine-learning methods: generalized boosting methods (GBM, also known as boosted regression trees (BRT)) (Elith et al., 2008), random forest (RF) (Breiman, 2001) and maximum entropy (MAXENT) (Phillips et al., 2004). All the models were implemented in the Biomod2 platform (Thuiller et al., 2013) using R-program (R Development Core Team 2013). The models were fitted using two sets of 131 predictors:

Model transferability was assessed using four-fold cross-validation. We applied a commonly used approach (Zimmermann et al., 2009; le Roux et al., 2013b; Aalto \& Luoto, 2014) to compare the predictive power of base (climateonly) and full (climate-plus-landscape) models by calculating the area under the curve of a receiver operating characteristic (AUC) plot (Fielding \& Bell, 1997), true skill statistics (TSS) and Cohen's Kappa coefficient (Allouche et al., 2006) based on the four evaluation runs (where the models calibrated with $75 \%$ of the data were evaluated with the withheld $25 \%$ of the data, and repeated for each of the four quarters of the data). A non-parametric Wilcoxon's test was employed to examine whether explanatory power and predictive accuracy differed significantly between models. 
All data were used for projecting species occurrences to current and future climatic conditions.

Occurrence probabilities were transformed to binary presence/absence predictions using a TSS cutoff, maximizing model accuracy, defined by BioMod2. In order to account for intermodal variability and to create the final maps of predicted species distributions, we used the consensus approach (Araújo \& New, 2007) to construct an ensemble of forecasts that combine the binary predictions from all models. Here we chose a majority's vote of a minimum of three out of five modelling techniques to denote a presence value for a given species inside a given $1 \mathrm{~km}^{2}$ grid cell (Figure S1).

For each species, variable influence was assessed in Biomod2 by randomizing each variable individually and then projecting the model with the randomized variable while keeping the other variables unchanged. The model predictions containing the randomized variable were then correlated with those of the original models. Finally, the importance of the variable was calculated as one minus the correlation, with higher values indicating higher predictor importance (Thuiller et al., 2009). This was repeated ten times for each modelling method and the resulting variable influence values were averaged.

\section{Definition of refugia}

Areas where the contemporary and future distributions of species overlap may act as refugia (Temunovic et al., 2013). By modelling contemporary and projected climates, we can identify these spatiotemporal species distribution overlaps (henceforth referred to as 'resilient cells'). Here, we regard these resilient cells as potential sites for in situ refugia where local species may be maintained, i.e. persist even under the assumption of no dispersal (Thomas et al., 2004; Pearson, 2006). In situ refugia are more likely to function as effective refugia as reaching them requires only local or no rangeshifts (Reside et al., 2014) and, by remaining within the present range of a given species, they provide a robust estimate of species persistence (Shoo et al., 2013).

To locate in situ refugia from SDM predictions we utilized a step-by-step approach as follows (Figure S1): firstly, as refugia are essentially species-specific (Provan \& Bennett, 2008; Stewart et al., 2010), we model the species separately to gain insights into their preferred environments. Next, the single-species predictions are projected separately into current climatic conditions and two future climate scenarios to locate cells where species occurrence is maintained both spatially and temporally (Shoo et al., 2013; Temunović et al., 2013). Finally, as favourable environmental conditions supporting refugia may overlap for several species (Hampe \& Petit, 2005; Keppel et al., 2012) and to increase prediction robustness, we stack projections of these resilient cells to locate sites where suitable conditions persist for several species. Areas with higher arctic-alpine species diversity are strong refugia candidates as they maximize available information and the probability of this diversity persisting under climate change. Consequently, sites harbouring several refugial 
species simultaneously are potentially very valuable for future conservation planning. Thus, we set a threshold of a minimum of five persisting species as a prerequisite for a resilient $1 \mathrm{~km}^{2}$ grid cell to be classified as a refugia.

\section{Results}

The use of topo-edaphic landscape-scale predictors significantly $(\mathrm{p}<0,001)$ improves the accuracy of SDMs developed for the studied arctic-alpine species. Based on the cross-validation runs, the mean AUC values improved from 0.77 (base i.e. climate-only model) to 0.86 (full i.e. climate-plus-landscape model). The corresponding TSS values improved from 0.51 to 0.62 , and Kappa values from 0.39 to 0.46 (Table 2). Lower standard deviations of the evaluation metrics in the full models also indicate greater model accuracy (Table 2).

The inclusion of landscape-scale predictors changes contemporary predictions of refugia as well as projections of species distributions and predictions of the availability of suitable environments for arctic-alpine species in a warming climate. Differences arise in both predictions of how many species are predicted to persist in a given refugia, as well as the total count i.e. spatial extent of refugial cells. The full model predicts fewer species range reductions and higher species persistence (Fig 2: b, d; Table S1): out of the 111 species, the full model locates refugia for 77 species in RCP 4.5 (climate-only model: 40 species) and 47 species in RCP 8.5 . Considerably less refugia were predicted by the full model into the more extreme RCP 8.5 (207 refugia; compared to 959 in RCP 4.5; Table S1). The base model does not project any refugia into RCP 8.5 (Fig 2: c). The spatial extent of refugial cells predicted by both models into RCP 4.5 shows a 79\% overlap (Fig 2: a, b). However, over 95\% of the refugial cells predicted by the full model for RCP 4.5 demonstrate a higher species persistence rate than predictions from the base model (Fig 2: b, d; Table S1).

Out of the 111 species included in the analysis, GDD3 was the most influential variable for most of the species ( $\mathrm{n}=69)$; calcareousness for 26 species; TWI for 13 species; and radiation was the most important variable for three species. An example of projected refugia for Alpine Mouse-ear (Cerastium alpinum) are shown in Figure S3. This small perennial herb shows a clear preference for high substrate calcareousness and cooler growing conditions offered by the regions refugia. There is a clear spatial prominence of refugial cells around the cooler, more calcareous mountainous regions of the study area (Figs $1 \&$ 2; Table S2; Figure S4: b-d). By including topo-edaphic landscape-scale variables, suitable environments for arctic-alpine species can, however, be projected into cells with a higher GDD3 than by accounting for climate alone. Aside from climatic differences, the refugia derived from full model predictions also exhibit slightly differing landscape conditions, here higher radiation, a higher cover of calcareous substrates and lower TWI (Table S2). 


\section{Discussion}

201 Our results demonstrate more detailed and accurate predictions of refugia following the inclusion of landscape-scale variables reflecting the topo-edaphic conditions to climate-only models. This is due to the limiting effect of using only climatic predictors that overlooks certain fine-resolution spatial and temporal (e.g. extent and persistence of suitable habitat, respectively) aspects of species distributions. In other words, consideration of landscape properties is required to capture the important topo-edaphic conditions shaping refugia distribution patterns in space and time (Austin \& Van Niel, 2011b), and our study shows that this is true also for high-latitude environments.

Refugia defined using both climate and topo-edaphic parameters, compared to refugia defined by climate alone, are more likely to continue to provide suitable conditions for a greater portion of arctic-alpine species growing in a given grid cell (Dobrowski, 2011; Keppel et al., 2012). The inclusion of topo-edaphic variables modifies climate-only models in a way that enables predictions of suitable future conditions into a number of cells with warmer average growing conditions. This significance of accounting for the topo-edaphic setting results partly from how it can modify the climatic conditions experienced by species (Austin \& Van Niel, 2011a; Lenoir et al., 2013). As seen for the example species, Alpine Mouse-ear, the climate-only model predicts species persistence in northern refugia, where temperatures are cooler (Figs S2 \& S4). The refugia show a more spatially dispersed pattern of persistence in a changed climate, but the forecasts of species persistence are made more optimistic through additions of topographic and edaphic predictors. Moreover, improvements to the models and derived predictions resulting from the incorporation of landscape-scale variables also emphasize an increase in species' tolerance in confronting climatic changes via edaphic conditions (Table S2; Fig S3). similar between the base and full model predictions for RCP 4.5. This is particularly evident in the northern regions of the study area where GDD3 levels remain favourably low for arctic-alpine species persistence. Areas with the least environmental change are more likely refugia candidates for most species within a grid cell (Reside et al., 2013) and, indeed, considerably less refugia were predicted by the full model into the more extreme RCP 8.5 (207 refugia; compared to 959 in RCP 4.5). The spatial distribution of these 207 refugial cells is more dispersed, suggesting that refugial species in a warmer future would need to rely on more isolated habitats to provide locally favourable landscapes. Though decreased by climatic changes, forecasts of species persistence in refugia are improved by even fairly simple topo-edaphic landscape properties at the mesoscale. Examining such grid cells where species can persist is a robust way of mapping 
distributional changes and refugia, though dispersal abilities and possible time lags of species responses to changing landscape configurations are also likely to contribute to the effectiveness of refugia. However, accounting for circumstances of little or no spatial overlap between current and future suitable environments would require information on species dispersal capacities (Reside et al., 2013; Reside et al., 2014) to ex situ refugia (Shoo et al., 2013) to enable more realistic estimates of species range-shift abilities to future refugia.

The distributions of a majority of the 111 arctic-alpine species studied here are projected to shrink following increases in temperature with most of the study region appearing as a matrix of unsuitable growing conditions for arctic-alpine species. Heterogeneous mountainous regions, such as the northern areas of our study landscape, are expected to be exceedingly important for refugia and the conservation of species (Loarie et al., 2008; Luoto \& Heikkinen, 2008; Scherrer \& Körner, 2011), especially for endemic mountain plants at risk from range reduction by upward displacement (Rull \& Vegas-Vilarrúbia, 2006). Indeed, our finding that the located refugia are offering conditions of lower soil moisture (as indicated by the variable TWI) is related to the assumption that steeper slopes, such as those found in the Scandes, are less likely to retain water (Beven \& Kirkby, 1979). The significance of these mountain refugia, however, is likely to be affected by species' properties such as growth form and dispersal capacity (Engler et al., 2009), and mountain refugia have been disputed to be of little avail to small, scattered populations of species (Birks, 2008). The reduction in available land area at higher elevations may also result in species' local extinctions (Patsiou et al., 2014). Nevertheless, the in situ refugial expanse in the mountainous area of the study region is projected to be an important deserves further investigation.

More generally, it needs to be acknowledged that evaluating the capability of refugia in promoting species persistence and ecosystem resilience is difficult due to the many uncertainties involved in predicting and modelling climate, changes therein, and species responses to these changes (Wiens et al., 2009; Reside et al., 2013; Shoo et al., 2013). For example, assuming uniform warming across a given landscape, or basing forecasts of changes in local climate on simple temperature-elevation correlations may over-emphasize the importance of relatively cool sites or higher elevations (Ashcroft, 2010). Essential aspects of future refugia research include investigating the dynamics of climatic decoupling between the atmosphere and terrain within arctic-alpine landscapes (Dobrowski, 2011; Scherrer \& Körner, 2011; Hylander et al., 2015), as we cannot surmise the effects of topography on climatic stability with the approach used here. A similar modelling framework could also be used to pinpoint individual at-risk species, specific areas or habitat types facing substantial changes in a warmer future (Thuiller et al., 2005; Williams et al., 2005; Loarie et al., 2008). Furthermore, though the landscape-scale predictors used here provide a solid basis for a comprehensive set of ecologically 
meaningful predictors, enumerating the significance of other variables, such as geomorphological disturbances (Randin et al., 2009; le Roux et al., 2013a; Slaton \& Linder, 2015), $\mathrm{CO}_{2}$ effects (Rickebusch et al., 2008) and biotic interactions (Godsoe et al., 2015; Mod et al., 2015), may also be necessary for more realistic predictions of refugia persistence (sensu Austin and Van Niel 2011b), though their relevance is likely to be further pronounced at finer spatial scales. ur results, highlighting the importance of topo-edaphic landscape-scale factors for modelling refugia as well as demonstrating changes in the extent and connectivity of suitable habitat, show there is a strong case for applying a similar approach at finer or even multiple scales to facilitate a more mechanistic approach to future refugia study.

\section{Conclusions}

268 Climate change projections suggest that returning to historical climatic conditions is highly improbable. Here we show 269 that, despite forecasted future regional warming, several resilient sites found in our study landscape are predicted to maintain suitable local environments due to topo-edaphic conditions. Refugia can be found in places where locally optimal environments remain constant across timescales and in which the effects of landscape preserve environmental conditions more reminiscent of suitable contemporary climates. Predictions of species responses to climate change based on climate alone may be inaccurate in estimating extinction risk as they neglect to consider topographic and edaphic processes affecting species distributions, and may fail to identify refugia where species can persist. Thus, models of species distributions and changes therein need to account for topo-edaphic landscape-scale variables to provide information on relevant spatial and temporal responses to environmental change and should thus be explicitly accounted for in future climate change impact assessment studies.

\section{Acknowledgements}

279 AN was funded by the Lapland Regional Fund (Finnish Cultural Foundation), Societas pro Fauna et Flora Fennica and 280 The Doctoral Program in Geosciences. We acknowledge funding from the Academy of Finland (Project Number 281 1140873). Also, HM was partly founded by the Alfred Kordelin Foundation and The Doctoral Program in Geosciences, and ML was partly funded by the Academy of Finland (Project Number 286950). We would also like to thank the Finnish

283 Museum of Natural History as one of the main contributors of the data on vascular plant species and Juha Aalto for 284 helping with gathering the environmental data and data analysis. 
290 Risto K. Heikkinen, Finnish Environment Institute, Natural Environment Centre, P.O. Box 140, FI-00251, Helsinki, 291 Finland

292 Email: risto.heikkinen@ymparisto.fi

293

294 Heidi K. Mod, Department of Geosciences and Geography, P.O. Box 64 (Gustaf Hällströmin katu 2a), FI-00014 295 University of Helsinki, Finland

296 Email: heidi.mod@helsinki.fi

297

298 Miska Luoto, Department of Geosciences and Geography, P.O. Box 64 (Gustaf Hällströmin katu 2a), FI-00014 University 299 of Helsinki, Finland

300 Email: miska.luoto@helsinki.fi 
Aalto, J. \& Luoto, M. (2014) Integrating climate and local factors for geomorphological distribution models. Earth Surface Processes and Landforms, 39, 1729-1740.

Aalto, J., Le Roux, P.C. \& Luoto, M. (2014a) The meso-scale drivers of temperature extremes in high-latitude Fennoscandia. Climate dynamics, 42, 237-252.

Aalto, J., Venäläinen, A., Heikkinen, R.K. \& Luoto, M. (2014b) Potential for extreme loss in high-latitude Earth surface processes due to climate change. Geophysical Research Letters, 41, 3914-3924.

Ackerly, D.D., Loarie, S.R., Cornwell, W.K., Weiss, S.B., Hamilton, H., Branciforte, R. \& Kraft, N.J.B. (2010) The geography of climate change: implications for conservation biogeography. Diversity and Distributions, 16, 476-487.

Allouche, O., Tsoar, A. \& Kadmon, R. (2006) Assessing the accuracy of species distribution models: prevalence, kappa and the true skill statistic (TSS). Journal of Applied Ecology, 43, 1223-1232.

Araújo, M.B. \& New, M. (2007) Ensemble forecasting of species distributions. Trends in Ecology \& Evolution, 22, 42-47.

Araújo, M.B. \& Peterson, A.T. (2012) Uses and misuses of bioclimatic envelope modeling. Ecology, 93, 15271539.

Ashcroft, M.B. (2010) Identifying refugia from climate change. Journal of Biogeography, 37, 1407-1413.

Austin, M. \& Smith, T. (1990) A new model for the continuum concept. Progress in Theoretical Vegetation Science, pp. 35-47. Springer.

Austin, M.P. \& Van Niel, K.P. (2011a) Impact of landscape predictors on climate change modelling of species distributions: a case study with Eucalyptus fastigata in southern New South Wales, Australia. Journal of Biogeography, 38, 9-19.

Austin, M.P. \& Van Niel, K.P. (2011b) Improving species distribution models for climate change studies: variable selection and scale. Journal of Biogeography, 38, 1-8.

Beauregard, F. \& de Blois, S. (2014) Beyond a climate-centric view of plant distribution: edaphic variables add value to distribution models. PloS one, 9, e92642.

Beven, K.J. \& Kirkby, M.J. (1979) A physically based, variable contributing area model of basin hydrology / Un modèle à base physique de zone d'appel variable de l'hydrologie du bassin versant. Hydrological Sciences Bulletin, 24, 43-69.

Birks, H.H. (2008) The Late-Quaternary history of arctic and alpine plants. Plant Ecology \& Diversity, 1, 135146.

Birks, H.J.B. \& Willis, K.J. (2008) Alpines, trees, and refugia in Europe. Plant Ecology \& Diversity, 1, $147-$ 160.

Botkin, D.B., Saxe, H., AraÚJo, M.B., Betts, R., Bradshaw, R.H.W., Cedhagen, T., Chesson, P., Dawson, T.P., Etterson, J.R., Faith, D.P., Ferrier, S., Guisan, A., Hansen, A.S., Hilbert, D.W., Loehle, C., Margules, C., New, M., Sobel, M.J. \& Stockwell, D.R.B. (2007) Forecasting the Effects of Global Warming on Biodiversity. BioScience, 57, 227.

Breiman, L. (2001) Random forests. Machine Learning, 45, 5-32.

Clarke, L., Edmonds, J., Jacoby, H., Pitcher, H., Reilly, J. \& Richels, R. (2007) Scenarios of greenhouse gas emissions and atmospheric concentrations. US Department of Energy Publications, 6.

Dobrowski, S.Z. (2011) A climatic basis for microrefugia: the influence of terrain on climate. Global Change Biology, 17, 1022-1035.

Dubuis, A., Giovanettina, S., Pellissier, L., Pottier, J., Vittoz, P. \& Guisan, A. (2013) Improving the prediction of plant species distribution and community composition by adding edaphic to topo-climatic variables. Journal of Vegetation Science, 24, 593-606.

Elith, J., Leathwick, J.R. \& Hastie, T. (2008) A working guide to boosted regression trees. J Anim Ecol, 77, 802-13.

Engler, R., Randin, C.F., Vittoz, P., Czáka, T., Beniston, M., Zimmermann, N.E. \& Guisan, A. (2009) Predicting future distributions of mountain plants under climate change: does dispersal capacity matter? Ecography, 32, 34-45.

Esri (2013) ArcScripts. Available at: (accessed 25 September 2013

Fielding, A.H. \& Bell, J.F. (1997) A review of methods for the assessment of prediction errors in conservation presence/absence models. Environmental conservation, 24, 38-49.

Fløjgaard, C., Normand, S., Skov, F. \& Svenning, J.C. (2009) Ice age distributions of European small mammals: insights from species distribution modelling. Journal of Biogeography, 36, 1152-1163. 
Franklin, J. (1995) Predictive vegetation mapping: geographic modelling of biospatial patterns in relation to environmental gradients. Progress in physical geography, 19, 474-499.

Fu, P. \& Rich, P.M. (1999) Design and implementation of the Solar Analyst: an ArcView extension for modeling solar radiation at landscape scales. Proceedings of the Nineteenth Annual ESRI User Conference (ed by, pp. 1-31.

Godsoe, W., Murray, R. \& Plank, M.J. (2015) Information on biotic interactions improves transferability of distribution models. The American Naturalist, 185, 281-290.

Guisan, A. \& Thuiller, W. (2005) Predicting species distribution: offering more than simple habitat models. Ecology letters, 8, 993-1009.

Guisan, A., Theurillat, J.P. \& Kienast, F. (1998) Predicting the potential distribution of plant species in an alpine environment. Journal of Vegetation Science, 9, 65-74.

Hampe, A. \& Petit, R.J. (2005) Conserving biodiversity under climate change: the rear edge matters. Ecology letters, 8, 461-467.

Hastie, T.J. \& Tibshirani, R.J. (1990) Generalized additive models. CRC Press.

Heikkinen, R.K., Luoto, M., Araújo, M.B., Virkkala, R., Thuiller, W. \& Sykes, M.T. (2006) Methods and uncertainties in bioclimatic envelope modelling under climate change. Progress in Physical Geography, 30, 751-777.

Hodd, R.L., Bourke, D. \& Skeffington, M.S. (2014) Projected range contractions of European protected oceanic montane plant communities: focus on climate change impacts is essential for their future conservation. PloS one, 9, e95147.

Hugall, A., Moritz, C., Moussalli, A. \& Stanisic, J. (2002) Reconciling paleodistribution models and comparative phylogeography in the Wet Tropics rainforest land snail Gnarosophia bellendenkerensis (Brazier 1875). Proceedings of the National Academy of Sciences, 99, 6112-6117.

Hylander, K., Ehrlen, J., Luoto, M. \& Meineri, E. (2015) Microrefugia: Not for everyone. Ambio, 44 Suppl 1, 60-8.

Keppel, G., Van Niel, K.P., Wardell-Johnson, G.W., Yates, C.J., Byrne, M., Mucina, L., Schut, A.G., Hopper, S.D. \& Franklin, S.E. (2012) Refugia: identifying and understanding safe havens for biodiversity under climate change. Global Ecology and Biogeography, 21, 393-404.

Kurtto, A. \& Lampinen, R. (1999) Atlas of the distribution of vascular plants in Finland: A digital view of the national floristic database. Acta Botanica Fennica, 67-74.

le Roux, P.C., Virtanen, R. \& Luoto, M. (2013a) Geomorphological disturbance is necessary for predicting fine-scale species distributions. Ecography, 36, 800-808.

le Roux, P.C., Lenoir, J., Pellissier, L., Wisz, M.S. \& Luoto, M. (2013b) Horizontal, but not vertical, biotic interactions affect fine-scale plant distribution patterns in a low-energy system. Ecology, 94, 671-682.

Lenoir, J., Graae, B.J., Aarrestad, P.A., Alsos, I.G., Armbruster, W.S., Austrheim, G., Bergendorff, C., Birks, H.J., Brathen, K.A., Brunet, J., Bruun, H.H., Dahlberg, C.J., Decocq, G., Diekmann, M., Dynesius, M., Ejrnaes, R., Grytnes, J.A., Hylander, K., Klanderud, K., Luoto, M., Milbau, A., Moora, M., Nygaard, B., Odland, A., Ravolainen, V.T., Reinhardt, S., Sandvik, S.M., Schei, F.H., Speed, J.D., Tveraabak, L.U., Vandvik, V., Velle, L.G., Virtanen, R., Zobel, M. \& Svenning, J.C. (2013) Local temperatures inferred from plant communities suggest strong spatial buffering of climate warming across Northern Europe. Global Change Biology, 19, 1470-81.

Loarie, S.R., Carter, B.E., Hayhoe, K., McMahon, S., Moe, R., Knight, C.A. \& Ackerly, D.D. (2008) Climate change and the future of California's endemic flora. PLoS One, $\mathbf{3}$, e2502.

Luoto, M. \& Heikkinen, R.K. (2008) Disregarding topographical heterogeneity biases species turnover assessments based on bioclimatic models. Global Change Biology, 14, 483-494.

McCullagh, P. \& Nelder, J.A. (1989) Generalized linear models. CRC press.

McCune, B. \& Keon, D. (2002) Equations for potential annual direct incident radiation and heat load. Journal of Vegetation Science, 13, 603-606.

Médail, F. \& Diadema, K. (2009) Glacial refugia influence plant diversity patterns in the Mediterranean Basin. Journal of Biogeography, 36, 1333-1345.

Mod, H.K., le Roux, P.C., Guisan, A. \& Luoto, M. (2015) Biotic interactions boost spatial models of species richness. Ecography, 38, 913-921.

Moore, I.D., Grayson, R. \& Ladson, A. (1991) Digital terrain modelling: a review of hydrological, geomorphological, and biological applications. Hydrological processes, 5, 3-30. 
Moss, R.H., Edmonds, J.A., Hibbard, K.A., Manning, M.R., Rose, S.K., Van Vuuren, D.P., Carter, T.R., Emori, S., Kainuma, M. \& Kram, T. (2010) The next generation of scenarios for climate change research and assessment. Nature, $\mathbf{4 6 3}, 747-756$.

NASA Land Processes Distributed Active Archive Center (2013) ASTER DEM. Available at: https://lpdaac.usgs.gov/data_access (accessed 07. 10. 2013).

Oksanen, L. \& Virtanen, R. (1995) Topographic, altitudinal and regional patterns in continental and suboceanic heath vegetation of northern Fennoscandia. Acta Botanica Fennica, 153, 1-80.

Patsiou, T.S., Conti, E., Zimmermann, N.E., Theodoridis, S. \& Randin, C.F. (2014) Topo-climatic microrefugia explain the persistence of a rare endemic plant in the Alps during the last 21 millennia. Global Change Biology, 20, 2286-300.

Pearson, R.G. (2006) Climate change and the migration capacity of species. Trends in Ecology \& Evolution, 21, 111-113.

Phillips, S.J., Dudík, M. \& Schapire, R.E. (2004) A maximum entropy approach to species distribution modeling. Proceedings of the twenty-first international conference on Machine learning (ed by, $\mathrm{p}$. 83.

Pirinen, P., Simola, H., Aalto, J., Kaukoranta, J., Karlsson, P. \& Ruuhela, R. (2012) Climatological statistics of Finland 1981-2010. Finnish Meteorological Institute Reports, 2012, 25.

Provan, J. \& Bennett, K.D. (2008) Phylogeographic insights into cryptic glacial refugia. Trends in Ecology and Evolution, 23, 564-71.

Randin, C.F., Engler, R., Normand, S., Zappa, M., Zimmermann, N.E., Pearman, P.B., Vittoz, P., Thuiller, W. \& Guisan, A. (2009) Climate change and plant distribution: local models predict high-elevation persistence. Global Change Biology, 15, 1557-1569.

Reside, A.E., Welbergen, J.A., Phillips, B.L., Wardell-Johnson, G.W., Keppel, G., Ferrier, S., Williams, S.E. \& VanDerWal, J. (2014) Characteristics of climate change refugia for Australian biodiversity. Austral Ecology, 39, 887-897.

Reside, A.E., VanDerWal, J., Phillips, B.L., Shoo, L.P., Rosauer, D.F., Anderson, B.J., Welbergen, J.A., Moritz, C., Ferrier, S. \& Harwood, T.D. (2013) Climate change refugia for terrestrial biodiversity. Available at: http://www.nccarf.edu.au/publications/climate-change-refugia-terrestrial-biodiversity (accessed 20. 08. 2013).

Riahi, K., Grübler, A. \& Nakicenovic, N. (2007) Scenarios of long-term socio-economic and environmental development under climate stabilization. Technological Forecasting and Social Change, 74, 887-935.

Riahi, K., Rao, S., Krey, V., Cho, C., Chirkov, V., Fischer, G., Kindermann, G., Nakicenovic, N. \& Rafaj, P. (2011) RCP 8.5-A scenario of comparatively high greenhouse gas emissions. Climatic Change, 109, 33-57.

Rickebusch, S., Thuiller, W., Hickler, T., Araujo, M.B., Sykes, M.T., Schweiger, O. \& Lafourcade, B. (2008) Incorporating the effects of changes in vegetation functioning and $\mathrm{CO} 2$ on water availability in plant habitat models. Biology Letters, 4, 556-559.

Root, T.L., Price, J.T., Hall, K.R., Schneider, S.H., Rosenzweig, C. \& Pounds, J.A. (2003) Fingerprints of global warming on wild animals and plants. Nature, 421, 57-60.

Roux, P.C.1., Virtanen, R., Heikkinen, R.K. \& Luoto, M. (2012) Biotic interactions affect the elevational ranges of high-latitude plant species. Ecography, 35, 1048-1056.

Rull, V. \& Vegas-Vilarrúbia, T. (2006) Unexpected biodiversity loss under global warming in the neotropical Guayana Highlands: a preliminary appraisal. Global Change Biology, 12, 1-9.

Sætersdal, M., Birks, H. \& Peglar, S. (1998) Predicting changes in Fennoscandian vascular-plant species richness as a result of future climatic change. Journal of Biogeography, 25, 111-112.

Scherrer, D. \& Körner, C. (2011) Topographically controlled thermal-habitat differentiation buffers alpine plant diversity against climate warming. Journal of biogeography, 38, 406-416.

Shoo, L.P., Hoffmann, A.A., Garnett, S., Pressey, R.L., Williams, Y.M., Taylor, M., Falconi, L., Yates, C.J., Scott, J.K. \& Alagador, D. (2013) Making decisions to conserve species under climate change. Climatic Change, 119, 239-246.

Skov, F. \& Svenning, J.C. (2004) Potential impact of climatic change on the distribution of forest herbs in Europe. Ecography, 27, 366-380.

Slaton, M.R. \& Linder, P. (2015) The roles of disturbance, topography and climate in determining the leading and rear edges of population range limits. Journal of Biogeography, 42, 255-266.

Smith, S.J. \& Wigley, T. (2006) Multi-gas forcing stabilization with Minicam. The Energy Journal, 373-391. 
Sormunen, H., Virtanen, R. \& Luoto, M. (2011) Inclusion of local environmental conditions alters highlatitude vegetation change predictions based on bioclimatic models. Polar Biology, 34, 883-897.

Stewart, J.R., Lister, A.M., Barnes, I. \& Dalén, L. (2010) Refugia revisited: individualistic responses of species in space and time. Proceedings of the Royal Society of London B: Biological Sciences, 277, 661-671.

Svenning, J.C., Normand, S. \& Kageyama, M. (2008) Glacial refugia of temperate trees in Europe: insights from species distribution modelling. Journal of Ecology, 96, 1117-1127.

Taberlet, P. (1998) Biodiversity at the intraspecific level: the comparative phylogeographic approach. Journal of Biotechnology, 64, 91-100.

Temunović, M., Frascaria-Lacoste, N., Franjić, J., Satovic, Z. \& Fernández-Manjarrés, J.F. (2013) Identifying refugia from climate change using coupled ecological and genetic data in a transitional Mediterraneantemperate tree species. Molecular ecology, 22, 2128-2142.

Thomas, C.D., Cameron, A., Green, R.E., Bakkenes, M., Beaumont, L.J., Collingham, Y.C., Erasmus, B.F., De Siqueira, M.F., Grainger, A. \& Hannah, L. (2004) Extinction risk from climate change. Nature, 427, 145-148.

Thuiller, W., Georges, D. \& Engler, R. (2013) biomod2: Ensemble platform for species distribution modeling. $R$ package version, $2, \mathrm{r} 560$.

Thuiller, W., Lafourcade, B., Engler, R. \& Araújo, M.B. (2009) BIOMOD - a platform for ensemble forecasting of species distributions. Ecography, 32, 369-373.

Thuiller, W., Lavorel, S., Araújo, M.B., Sykes, M.T. \& Prentice, I.C. (2005) Climate change threats to plant diversity in Europe. Proceedings of the National Academy of Sciences of the united States of America, 102, 8245-8250.

Tikkanen, M. (2005) Climate. The physical geography of Fennoscandia (ed. by M. Seppälä). Oxford University Press, Oxford

Waltari, E., Hijmans, R.J., Peterson, A.T., Nyári, Á.S., Perkins, S.L. \& Guralnick, R.P. (2007) Locating Pleistocene refugia: comparing phylogeographic and ecological niche model predictions. PLoS one, 2

Van Vuuren, D.P., Edmonds, J., Kainuma, M., Riahi, K., Thomson, A., Hibbard, K., Hurtt, G.C., Kram, T., Krey, V. \& Lamarque, J.-F. (2011) The representative concentration pathways: an overview. Climatic change, 109, 5-31.

Wiens, J.A., Stralberg, D., Jongsomjit, D., Howell, C.A. \& Snyder, M.A. (2009) Niches, models, and climate change: assessing the assumptions and uncertainties. Proceedings of the National Academy of Sciences, 106, 19729-19736.

Williams, P., Hannah, L.E.E., Andelman, S., Midgley, G.U.Y., AraÚJo, M., Hughes, G., Manne, L., MartinezMeyer, E. \& Pearson, R. (2005) Planning for Climate Change: Identifying Minimum-Dispersal Corridors for the Cape Proteaceae. Conservation Biology, 19, 1063-1074.

Wise, M., Calvin, K., Thomson, A., Clarke, L., Bond-Lamberty, B., Sands, R., Smith, S.J., Janetos, A. \& Edmonds, J. (2009) Implications of limiting CO2 concentrations for land use and energy. Science, 324, 1183-1186.

Zimmermann, N.E., Yoccoz, N.G., Edwards, T.C., Jr., Meier, E.S., Thuiller, W., Guisan, A., Schmatz, D.R. \& Pearman, P.B. (2009) Climatic extremes improve predictions of spatial patterns of tree species. Proceedings of the National Academy of Sciences of the United States of America, 106 Suppl 2, 197238.

Manuscript Received d mmm., 20yy, revised and accepted d mmm., 20yy 
507 Table 1 Descriptions of the four focal environmental variables with their minimum (Min.), median (Med.), mean and 508 maximum (Max.) values

\begin{tabular}{|c|c|c|c|c|c|}
\hline Variable & Description & Min. & Med. & Mean & Max. \\
\hline GDD3 (contemporary) & Growing degree days (annual accumulated & 163 & 810 & 784 & 1050 \\
\hline (under RCP 4.5) & daily temperature sum above $3^{\circ} \mathrm{C}$; unit ${ }^{\circ} \mathrm{C}$ ) & 374 & 1247 & 1204 & 1489 \\
\hline (under RCP 8.5) & & 633 & 1620 & 1587 & 1964 \\
\hline Radiation & Potential annual direct radiation $\left(\mathrm{MJ} / \mathrm{cm}^{2} / \mathrm{a}\right)$ & 0.28 & 0.43 & 0.43 & 0.62 \\
\hline TWI & Topographic wetness index & 5.58 & 6.93 & 6.95 & 8.70 \\
\hline Calcareousness & Cover of calcareous substrates $(\%)$ & 0 & 6.7 & 13.0 & 90.3 \\
\hline
\end{tabular}


510 Table 2 The model evaluation statistics for the base (climate-only) and full (climate-plus-landscape) models showing the 511 mean and standard deviation (SD) of the evaluation metrics over four cross-validation runs. Wilcoxon signed rank test p512 values show change in predictive ability $(* * *=$ highly significant). AUC improved for 104; TSS for 10; and Kappa for 51399 out of 111 species

\begin{tabular}{lcccccc}
\hline & \multicolumn{2}{c}{ AUC } & \multicolumn{2}{c}{ TSS } & \multicolumn{2}{c}{ Kappa } \\
\cline { 2 - 7 } & Base & Full & Base & Full & Base & Full \\
\hline Mean \pm SD & $0.77 \pm 0.09$ & $0.86 \pm 0.06$ & $0.51 \pm 0.14$ & $0.62 \pm 0.13$ & $0.39 \pm 0.21$ & $0.46 \pm 0.16$ \\
\hline p-value & \multicolumn{2}{c}{$<.001 * * *$} & \multicolumn{2}{c}{$<0.001 * * *$} & $<0.001 * * *$ \\
\hline
\end{tabular}

514 
515 Fig 1. The location and elevation of the study area in northern Fennoscandia. We used data from whole area for training 516 the models, but excluded non-analogue regions from the projections (white dashed line)

518 Fig 2. Refugia in two Representative Concentration Pathway (RCP) scenarios (RCP 4.5 a-b; RCP 8.5 c-d) of future 519 climate according to base models (climate-only; a, c) and full models (climate-plus-landscape; b, d). The full models predict a higher relative species persistence from contemporary to future climates. No refugia were predicted for scenario

521 RCP 8.5 by the base model. The legend applies throughout 
Figure S1: An outline of the modelling framework used. We combined model predictions for 111 arctic-alpine plant species to estimate current and projected species distribution and identify refugia at a $1 \mathrm{~km}^{2}$ resolution. To enable the comparison of species' distributional changes, we ran the predictions for contemporary climate as well as two Representative Concentration Pathways (RCPs 4.5 and RCP 8.5). Two sets of predictors were used: climate-only (growing degree days (GDD3)); and climate-plus-landscape, which included additional landscape-scale predictors: potential solar radiation (RAD); calcareousness (CALC); and topographic wetness index (TWI). Observed species distributions were related to the set of predictors using five statistical modelling techniques: generalized linear modeling (GLM), generalized additive modeling (GAM), generalized boosting methods (GBM), random forest (RF) and maximum entropy (MAXENT). All the models were implemented in the Biomod2 platform under R-program

Table S1: Summary statistics for arctic-alpine species persistence within refugia; the number (n) and proportion (\%) of species persisting in refugia according to the two model structures used and two scenarios of future climate. No refugia were predicted for scenario RCP 8.5 by the base model. The total count of cells used in the analysis was 15622

Figure S2: Predicted contemporary and future distributions of Alpine Mouse-ear (Cerastium alpinum) in the study area. The predicted distributions were modelled into two scenarios of future climates (RCP 4.5 and RCP 8.5) according to two sets of predictors: climate-only (base model) and climate-plus-landscape (full model)

Figure S3: Box-and-whisker plot showing the mean variable importance values based on the full model across all species and across the five modelling techniques utilized (boxplot represents median, first and third quartiles; the whiskers show the interquartile range). The variables included in the full model are growing degree days (GDD3), calcareousness (CALC), potential solar radiation (RAD) and topographic wetness index (TWI). See table 1 for a full description of each variable. Outliers are excluded for clarity

Table S2: Summary statistics for refugia located by the base (climate-only) and full (climate-plus-landscape) models under Representative Concentration Pathway (RCP) 4.5 and the full model for RCP 8.5 (the base-model for RCP 8.5 found no refugia). The full set of variables are growing degree days (GDD3), calcareousness, potential solar radiation (RAD) and topographic wetness index (TWI). See table 1 for a full description of each variable and for comparison with contemporary climatic conditions

Figure S4. Spatial characteristics of the predictor variables: growing degree days (GDD3; ${ }^{\circ} \mathrm{C}$ ) for the contemporary climate 1981-2010 (a), and GDD3 for the two Representative Concentration Pathway (RCP) scenarios used: RCP 4.5 (b) and RCP 8.5 (c); calcareousness (d; \%); potential solar radiation (e; $\mathrm{MJ} / \mathrm{cm}^{2} / \mathrm{a}$ ); and topographic wetness index (TWI) (f). 


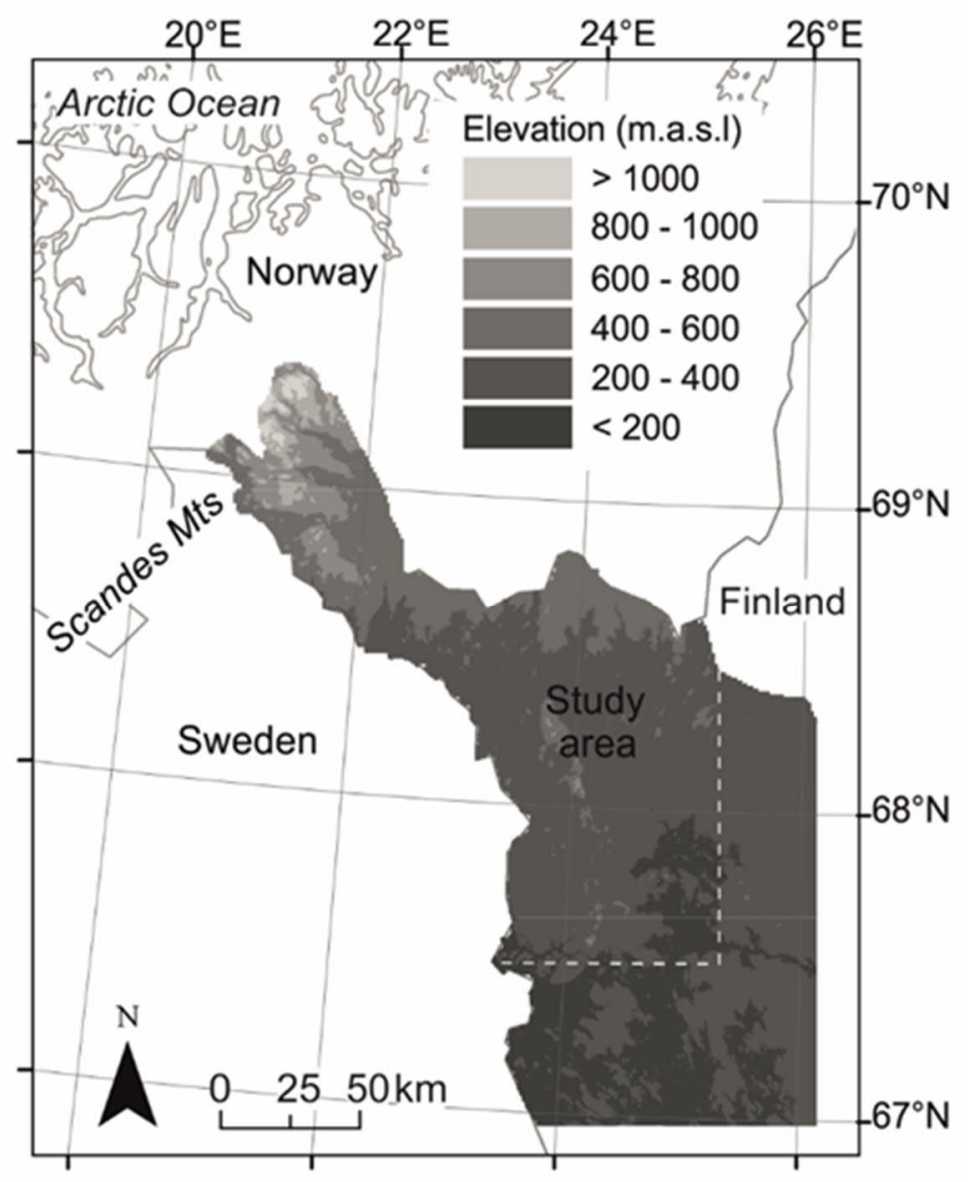

562

563

Figure 1.

564

565

566

567

568

569

570

571

572

573

574

575

576

577

578

579

580

581

582 


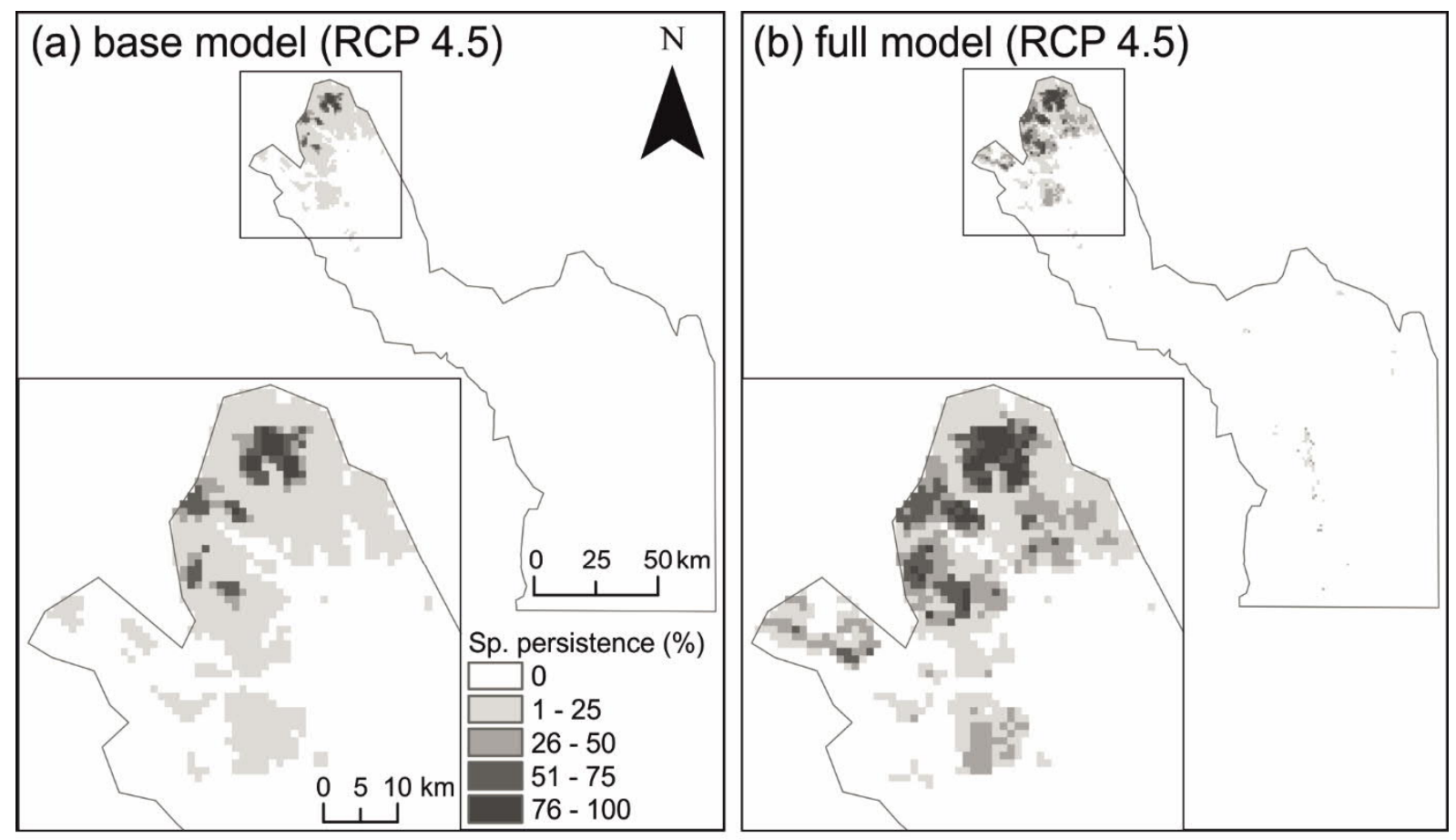

(c) base model (RCP 8.5)

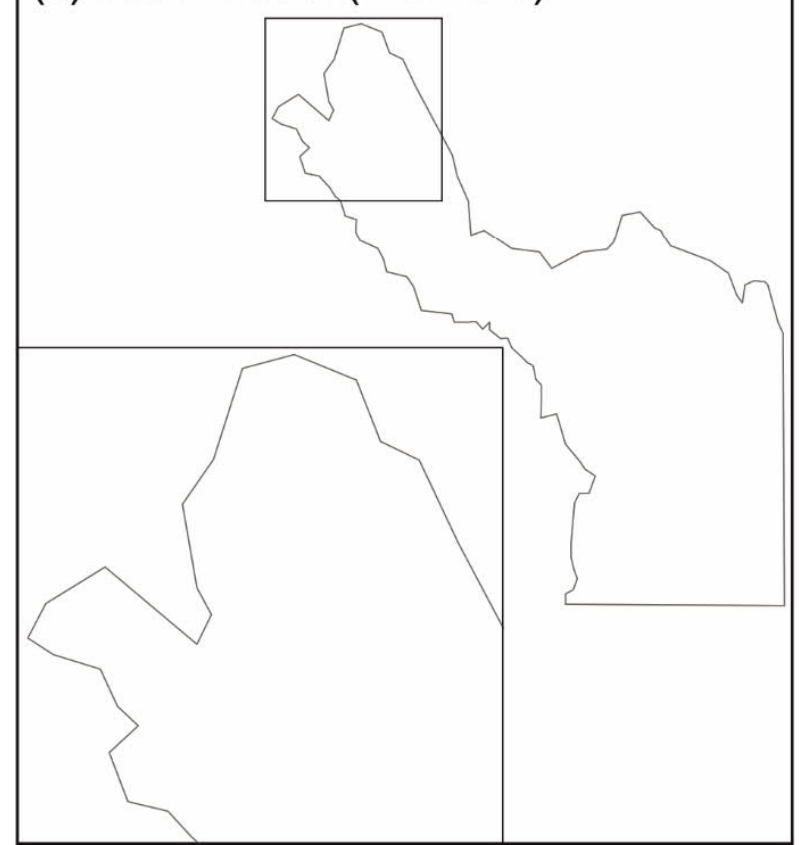

(d) full model (RCP 8.5)

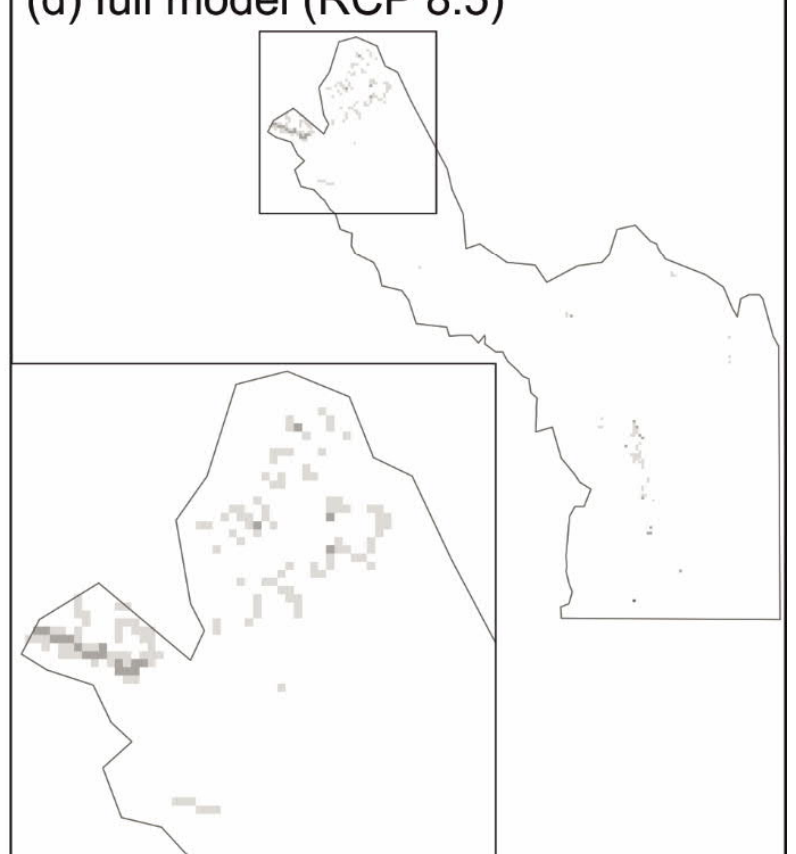

